\title{
Prosecutor's Demand In Delimination Form of Children's Independence As A Form Of Legal Protection
}

\author{
Suhardjono*) and Siti Ummu Adillah**) \\ *) Master of Law Program, Faculty of Law Universitas Islam Sultan Agung email \\ suhardjono70@gmail.com \\ ${ }^{* *}$ ) Faculty of Law Universitas Islam Sultan Agung
}

\begin{abstract}
The purpose of this study is to find out and analyze whether the prosecutor's demands containing the deprivation of liberty against children have been appropriately applied in the context of legal protection to children, especially in sexual crimes committed by children against children. The approach method used in this research is empirical juridical with the specification in this research is descriptive analysis, which describes the applicable laws and regulations associated with legal theories in the practice of implementing positive law concerning problems. The results obtained are that the prosecutor's demands in the form of formal deprivation of liberty and seen from the aspect of legal objectives are in accordance with Act No. 11 of 2012 concerning the Juvenile Criminal Justice System, besides that from a sociological and philosophical point of view it is felt to be comparable to trauma and suffering a lifetime experienced by the victim's child in facing his future.

Keywords: Prosecutors' Demands; Legal protection; Child.
\end{abstract}

\section{Introduction}

In a legal state, there is a principle that applies that the state recognizes and protects individual rights. Recognition of individual rights is guaranteed in the principle of equality before the law so that if in a country there is equality before the law, there will also be equal treatment for everyone. Equality before the law guarantees access to justice and one form of access to justice is the guarantee of human rights for everyone and is one of the elements to obtain justice for all. ${ }^{1}$

Conventional crimes in their development no longer involve adult perpetrators, but in several crimes that occur, perpetrators with the "Child" category also commit many conventional crimes, whether committed alone or together with adults or even committed by children together. The same as other child offenders. From this fact, legal protection for children then becomes a very serious problem to be applied in law enforcement practice.

Children are a mandate and gift from God Almighty who has the dignity and worth as a whole human being. Children are part of the younger generation as one of the human resources who are the potential and successors of the ideals of the nation's struggle, which have a strategic role and have special characteristics and characteristics, require guidance and protection in order to ensure physical, mental

${ }^{1}$ Sri Sumarwani, 2012, Pidana dan Hak-Hak Manusia, Ed. I, Semarang, UNDIP Pres, p.37. 
and social growth and development whole, harmonious, harmonious, and balanced. According to the Convention on the Rights of the Child in Article 1 part 1, it is stated that a child is part of every human being who is under the age of 18 years unless under the law applicable to children, maturity is reached earlier. ${ }^{2}$

Children in the eyes of parents and families are a great hope and pride in themselves and become the figure of the nation's next generation. In the view of religion, children are gifts to be grateful for as sustenance given by the Creator. And children are an inseparable part of human survival and the survival of a nation and state. $^{3}$

Legal protection for children can be done as an effort to protect the law against various freedoms and children's rights (fundamental rights and freedoms of children) as well as various interests related to children's welfare. So legal protection for children covers a very broad scope. ${ }^{4}$ Legal protection for children is regulated in Act No. 23 of 2002 concerning Child Protection which was promulgated on October 22, 2002 which in its development was later amended by Act No. 35 of 2014 concerning Amendments to Act No. 23 of 2002 concerning Child Protection and Government Regulation in Lieu of Act No. 1 of 2016 concerning the Second Amendment to Act No. 23 of 2002 concerning Child Protection.

Child protection, both for children who are in conflict with the law or child victims of criminal acts, needs to be carried out with seriousness, because the existence of immature children is not able to distinguish good and bad and is unable to think rationally, thus requiring legal protection. Quoting Ari Yudistira and Widayati's opinion that: "children are victims, considering that children are still at an immature age who cannot distinguish between good or bad and right or wrong, coupled with various factors that easily influence children to commit these crimes, so they need legal protection". 5

Government Regulation in Lieu of Act No. 1 of 2016 in its development has subsequently been established as law with the enactment of Act No. 17 of 2016 concerning the Stipulation of Government Regulation in Lieu of Act No. 1 of 2016 concerning Child Protection into Law. In the General Provisions of the Child Protection Act, it is stated that a child is someone who is not yet 18 (eighteen) years old, including a child who is still in the womb.

Children are also declared entitled to receive Child Protection, namely all activities to guarantee and protect children and their rights so that they can live, grow, develop and participate optimally in accordance with human dignity and protection from violence and discrimination. Thus, children have the right to be

\footnotetext{
${ }^{2}$ Rachmadhani Mahrufah Riesa Putri, Tindak Pidana Penyalahgunaan Narkotika Pada Anak Dalam Hukum Positif Di Indonesia, Recidive, Volume 8 No. 3, Sept.-Dec 2019, p.202-208

3 I Dewa Putu Gede Anom Danujaya, Formulasi Model Sistem Pemidanaan Anak Di Indonesia, Jurnal Daulat Hukum, Volume 1 Issue 1, March 2018, p.109

4Barda Nawawi Arief, 1998, Beberapa Aspek Kebijakan dan Pengembangan Hukum Pidana, Bandung, PT. Citra Aditya Bakti, p. 153

${ }^{5}$ Ari Yudistira and Widayati, The Investigation Process of Prospective Children in Criminal Action, Jurnal Daulat Hukum, Volume 4 Issue 1, March 2021, p.21
} 
legally protected from acts of violence, both physically, psychologically and sexually. ${ }^{6}$

One of the considerations in the law states that in order for every child to be able to take on these responsibilities, he needs to have the widest possible opportunity to grow and develop optimally, physically, mentally and socially and with noble character, so it is necessary to protect and to realize the welfare of children by providing guarantees for the fulfillment of their rights and treatment without discrimination. Protection and fulfillment of children's rights is an absolute thing that must be done because children as creatures of God Almighty and social beings, from the time they are in the womb until they are born have the right to live and be independent and receive good protection from their parents, family, community, nation and country. ${ }^{7}$

Children who become perpetrators of crimes (Child offenders in this law are referred to as one part of the definition of Children in Conflict with the Law) are also given adequate protection and the forms of protection are regulated in detail in Act No. 11 of 2012 concerning Juvenile Criminal Justice System.

Regarding the justice system for children, based on the explanation in the Criminal Code, in Act No. 11 of 2012 concerning the Juvenile Criminal Justice System and in Act No. 35 of 2014 concerning Child Protection, there are provisions stating that the settlement of cases of children in conflict with the law implemented through diversion. ${ }^{8}$

Against children who are victims of a crime committed by perpetrators who are also still in the category of children, the protection provided by the law is still often a matter of debate because the existing laws, especially Act No. 23 of 2002 and its amendments, if observed, still provide many benefits protection for child offenders compared to child victims of crime.

This study aims to determine and analyze whether the prosecutor's demands containing the deprivation of liberty against children have been appropriately applied in the context of legal protection to children, especially in sexual crimes committed by children against children.

\section{Research Methods}

This research uses the approach method empirical juridical and research specifications used are descriptive analysis using primary data, namely the results of interviews with sources, namely the Public Prosecutor and structural officials at the Semarang District Attorney's Office related to the handling of cases. Apart from that, secondary data taken from the literature study is also used. The data obtained is then analyzed logically and systematically then the results will be presented descriptively.

${ }^{6}$ Maidun Gultom, 2013, Perlindungan Hukum Terhadap Anak Dan Perempuan, Bandung, Refika Aditama, p. 2

${ }^{7}$ HR Abdussalam and Adri Deasasfuryanto, 2014, Hukum Perlindungan Anak, Jakarta, PTIK, p.1. ${ }^{8}$ Rendy Surya Aditama, Umar Ma'ruf, Munsharif Abdul Chalim, Kebijakan Hukum Pidana Terhadap Anak Sebagai Pelaku Kejahatan Psikotropika Di Kepolisian Resor Magelang, Jurnal Daulat Hukum, Vol. 1. No. 1 March 2018, p.121 


\section{Results and Discussion}

Children as national development assets must be considered and taken into account in terms of quality and their future. Without building reliable quality and a clear future for children, national development will be difficult to implement and the future fate of the nation will be difficult to imagine. Judging from the juridical aspect of the definition of a child in the eyes of Indonesian positive law (ius contitutum/ius operatum) a child is commonly defined as a person who is not yet an adult (minderjarig / person under age), people who are under age / underage conditions (minderjarig / inferiority) or often also referred to as a child under the supervision of a guardian (minderjarig ondervoordij). ${ }^{9}$

In carrying out social interactions in society, children often do things that should not be done, which results in children having to deal with the law to solve the cases they face and often end up being punished. With the punishment / punishment is expected to provide a deterrent effect and provide lessons for children so that in the future they can behave better and not repeat the act. ${ }^{10}$ The behavior of children in conflict with the law is not solely influenced by changes in the child's growth and development. There are various factors that influence children's behavior patterns that tend to lead to negative actions including unlawful acts. ${ }^{11}$

According to Act No. 11 of 2012 concerning the Juvenile Criminal Justice System, what is meant by children in conflict with the law are children in conflict with the law, children who are victims of criminal acts, and children who are witnesses of criminal acts. Based on this definition, it can be stated that there are three categories of children in conflict with the law, namely: ${ }^{12}$

- Children in conflict with the law, namely children as perpetrators of criminal acts.

- Children who are victims of criminal acts, namely children who experience physical, mental, and/or economic losses caused by criminal acts.

- Children who are witnesses to criminal acts, namely children who can provide information for the purposes of investigation, prosecution, and examination in court about a criminal case that has been heard, seen, and/or experienced by him/herself.

That the three categories of children in conflict with the law are given the same legal protection by law and in the ongoing criminal justice process all their rights must be guaranteed together. The problem that arises is that it is so difficult

\footnotetext{
9 Nandang Sambas, 2013, Peradilan Pidana Anak di Indonesia dan Instrumen International Perlindungan Anak serta Penerapannya, Yogyakarta, Graha Ilmu, p.4.

${ }^{10}$ Putu Yudha Cahyasena, I Ketut Rai Setiabudhi, I Made Tjatrayasa, Tinjauan Kriminologis Terhadap Anak Yang Berkonflik Dengan Hukum (Study Kasus Di Bapas Kelas Ii Mataram), Kertha Wicara, Vol. 05, No. 03, April 2016, p.3

11Bagus Gede Brahma Putra, Gde Made Swardhana, Sagung Putri M.E. Purwani, Anak Berhadapan Dengan Hukum Ditinjau Dari Aspek Kriminologi (Study Kasus Di Lembaga Pembinaan Khusus Anak Kelas Ii Karangasem), Kertha Wicara, Vol. 07, No. 01, January 2018, p.6

${ }^{12}$ Analiansyah and Syarifah Rahmatillah, Perlindungan Terhadap Anak Yang Berhadapan Dengan Hukum (Studi Terhadap Undang-undang Peradilan Anak Indonesia dan Peradilan Adat Aceh), Gender Equality: Internasional Journal of Child and Gender Studies, Vol. 1, No. 1, March 2015 p.54
} 
to provide equal, balanced and fair legal protection for children who are victims of crime (child victims) compared to providing legal protection to categories of children who are in conflict with other laws, especially children as perpetrators of crimes.

Regarding the principle of protection, especially for children who are in conflict with the law, it is contained in the Convention on the Rights of the Child which has been regulated in Act No. 3 of 1997 concerning Juvenile Court. This is contained in the point of consideration which in principle explains that the administration of courts for children needs to be done specifically, considering that children have limitations in understanding what they are learning so that they tend to have a negative influence on them. ${ }^{13}$

Legal protection for children who are victims of crime itself can essentially be carried out properly and fairly if it is associated with adult perpetrators, meaning that the protection of children who become victims of crime by adults can be carried out optimally according to the provisions in Act No. 11 of 2012 concerning the Juvenile Criminal Justice System.

However, it will be a very difficult problem if the perpetrator and the victim in a crime are both categories of children, this difficulty occurs because the law provides an obligation to provide legal protection together against two conflicting interests, namely legal protection for children perpetrators of crime and on the other hand must also be given the same legal protection for children who are victims of crime.

The problem that arises is of course regarding the model or form of protection that can be said to be fair and balanced for children who are perpetrators of crimes, but in the same position it is felt to be fair for other children who are victims of their crimes, so from a philosophical and sociological point of view it is necessary to see how it should be. The law must provide protection for child victims equally, balanced and fair as well as protection given to child perpetrators of crime, so that it is felt capable of providing benefits also for child victims.

When discussing the issue of legal protection for children, both in the capacity as perpetrators of crimes and child victims of a crime, of course it cannot be separated from discussions regarding law enforcement in cases of children, including those related to the imposition of crimes and actions against children who are perpetrators of crimes. The imposition of this crime in practice also should not be intended solely in the context of retaliation for the perpetrator's actions as espoused in the theory of the purpose of punishment that was followed at the end of the 18th century, namely Revenge Theory (vergelding or vergeltung or absolute theory) which states that the legal basis of a punishment is the mind for retaliation. ${ }^{14}$

13 Mahendra Ridwanul Ghoni, P.Pujiyono, Perlindungan Hukum Terhadap Anak yang Berhadapan dengan Hukum Melalui Implementasi Diversi di Indonesia, Jurnal Pembangunan Hukum Indonesia, Volume 2, Nomor 3 of 2020, p.331-342

${ }^{14}$ Bambang Purnomo, 1982, Asas-Asas Hukum Pidana, Jakarta, Ghalia Indonesia, p.27. 
Positive law in Indonesia currently follows the theory Combined theory which states that punishment should be based on the objectives of the elements of retaliation and maintaining public order which is applied in combination by focusing on one of its elements without eliminating the other elements or all existing elements.

According to the literature on the Criminal Code (Act No. 1 of 1946) by looking at the system and composition that has not changed from the main legal material (WvS Ned), it can be said that the Criminal Code has a criminal purpose with a compromising flow or combined theory that includes all aspects that develop in it. While correctional is a crystallization of criminal aspects which are prioritized for guiding and coaching by officers who carry out crimes. ${ }^{15}$

Regarding the rights of children in conflict with the law themselves, the detailed arrangements are contained in Article 3 letters a to p of Act No. 11 of 2012 concerning the Juvenile Criminal Justice System. In Article 4 letters a to $g$ of the Child Criminal Justice System Act, specifically for children who are undergoing a criminal period, special rights are also given, including getting a reduction in their criminal period, getting assimilation and other rights.

The rights granted by the law, especially in Act No. 11 of 2012 concerning the Juvenile Criminal Justice System, several types of rights can be enjoyed directly simultaneously by the three categories of children in conflict with the law, whether children, child victims or witnesses, but If we look closely, these rights are mostly aimed at the interests of the child (the perpetrator of the crime) so that if we compare it in the case of the child perpetrator and the victim who is also a child, the portion of legal protection provided in the form of rights in the law mentioned above tends to will not be the same between what is received by the child as the perpetrator of the crime and what is received by the child as the victim.

The rights of the victim's child itself have only recently been regulated in Act No. 35 of 2004 concerning Amendments to Act No. 23 of 2002 concerning Child Protection, which in Article 59 paragraph (2) letters e, f, h, i, j and k specifically mentions the 'Child of the Victim' while in other provisions it refers to the word 'Child'. The state has a big role in protecting children's rights which is realized by issuing regulations regarding the provision of protection for children so that there is legal guarantee for child protection activities which will have an impact on the continuity of child protection activities and prevent fraud in the implementation of child protection. ${ }^{16}$ The provisions of Article 59 paragraph (2) of Act No. 23 of 2002 above state that the Government, Regional Governments and other State Institutions are obliged to provide special protection to:

- Children who are victims of narcotics, alcohol, psychotropic and other addictive substances abuse.

- Children who are victims of pornography.

- Child victims of kidnapping, sale, and/or trafficking.

- Child victims of physical and/or psychological violence.

15Ibid. p. 33

16 Rini Fitriani, Peranan Penyelenggara Perlindungan Anak Dalam Melindungi dan Memenuhi HakHak Anak, Jurnal Hukum Samudra Keadilan, Vol 11, No 2, July-December 2016, p.250-258 
- Child victims of sexual crimes.

- Children victims of terrorist networks.

The protection that must be provided by the State and Government as stated in the provisions of Article 59 paragraph (2) of Act No. 23 of 2002 is very closely related to the law enforcement process. Law enforcement is essentially a process to realize legal goals, legal ideas so that they become reality. Law enforcement is a process of activity or activity, one of which is carried out by law enforcement (POLRI/PPNS investigators, prosecutors and judges), and to produce good law enforcement, the process of each stage in law enforcement must be carried out properly and correctly. ${ }^{17}$

Although the law has provided arrangements regarding special protection for Child Victims as mentioned above, in the context of the case handling process regulated in Act No. 11 of 2012 concerning the Juvenile Criminal Justice System starting from the investigation, prosecution and trial stages, the portion The legal protection received by the child victim is felt to be less when compared to that received by the child (the perpetrator of the crime). The concept of child protection does not only include a space for physical and spiritual protection of children but also regarding the protection of all rights and interests that can ensure normal growth and development, both spiritually, physically and socially. This is related to the position of children as the younger generation who will continue the noble ideals of the nation, future leaders of the nation and as a source of hope for previous generations, so that children need to have the widest opportunity to grow and develop properly both physically and mentally, spiritual, physical and social. Child protection is an effort and activity of all levels of society in various positions and roles who are fully aware of the importance of children for the homeland and nation in the future. ${ }^{18}$

As a study material in writing this journal, data will be presented on a criminal case that was prosecuted at the Semarang District Attorney's Office ${ }^{19}$ involving child perpetrators and victims as well as children, namely the crime of "intentionally deceiving and persuading children to have intercourse with him or with other people", violating the provisions of article 81 paragraph (2) of the Child Protection Act No. 17 of 2016 concerning Stipulation of Government Regulations Substitute Act No. 1 Of 2016 concerning Child Protection into law.

The case in question involves the perpetrator and the victim who are both qualified as children because they are under 18 years old (children are 17 years old and child victims are 14 years old) and the case is carried out by children together with adults. The case has been prosecuted by the Public Prosecutor at the Semarang

\footnotetext{
${ }^{17}$ Sri Endah Wahyuningsih, Rismanto, Kebijakan Penegakan Hukum Pidana Terhadap Penanggulangan Money Laundering Dalam Rangka Pembaharuan Hukum Pidana Di Indonesia, Jurnal Pembaharuan Hukum, Volume II No. 1 January - April 2015, p.46-56

18 Maidin Gultom, Op.Cit, p.33

19 Criminal Case Files at the Semarang District Attorney's Office Case Register Number: PDM05/M.3.42/Eku.2/01/2020 on behalf of Bagus Andriyanto Bin Ahmad Sujio.
} 
District Prosecutor's Office and decided by the Ungaran District Court Judge ${ }^{20}$ with the verdict, which reads:

- Sentencing BAGUS ANDRIYANTO Bin AHMAD SUJIO with criminal Guidance in Institutions at the LPKA (Special Guidance for Children) Kutoarjo in Purworejo for 24 (twenty four) months and Job Training at the Wira Adhi Karya Ungaran Child Social Service Home for 3 (three) month.

- Etc.

As for the other defendants who committed criminal acts together with Child of Bagus Andriyantio Bin Ahmad Sujio, namely adult defendants on behalf of M RIZKI ILHAM Case Register Number: PDM-06/M.3.42/Eku.2/01/2020 decided by the PN Judges Ungaran with the decision Number: 15/Pidsus/2020/PN Unr dated March 24, 2020 in the form of imprisonment for 5 (five) years and 4 (four) months.

From the demands of the Public Prosecutor and the judge's decision against Child of Bagus Andriyantio Bin Ahmad Sujio, it can be seen that the Prosecutor has demanded that 2 (two) main crimes be imposed against the Child as a criminal with the Criminal Code of Institutional Guidance and Job Training.

As is known, the types of crimes against children regulated in Act No. 11 of 2012 concerning the Juvenile Criminal Justice System as stated in article 71 consist of: basic and additional criminal penalties, the main criminal itself consists of: Warning Crime, Criminal Conditions, Supervision of job training, coaching in institutions and prisons.

As an alternative to imposing criminal sanctions, the Juvenile Criminal Justice System law also provides an opportunity for ACTION to be imposed on children who commit criminal acts, in the form of: Returning to parents/guardians, Handing over to someone, Treatment in a mental hospital, Nursing in LPKS, Obligation to attend formal education and/or training held by the government or private bodies, Revocation of Driving License and Repair due to criminal acts.

Regarding the discussion of aspects of legal protection given to children who are perpetrators of crimes, the criminal charges submitted by the Public Prosecutor at the Semarang District Prosecutor's Office above, seen from the legal aspects both formal and material and also from the aspect of the purpose of the law itself, the criminal charges it is said to have complied with the provisions of the existing legislation and has fulfilled a sense of justice because the Prosecutor has demanded 2 (two) main crimes as well as an effort to provide a deterrent effect for the perpetrators in addition to of course by considering the future of the child who is the perpetrator of the crime.

Viewed from the point of view of legal philosophy, namely basing on a sense of justice and its benefits, especially justice seen from the point of view of the interests of the victim's child and his family, and besides that if seen also from a sociological aspect, the prosecutor's demands are also felt to have been comparable to the suffering and trauma experienced by the victim. Child victims in facing their future because child perpetrators of crimes have factually received a criminal which includes aspects of deprivation of their rights and independence, because the child

\footnotetext{
20Ungaran District Court Decision Number: 2/Pid.Sus-Anak/2020/PN Unr dated February 25, 2020 on behalf of Bagus Andriyanto Bin Ahmad Sujio.
} 
perpetrator must undergo punishment in the form of coaching in the institution/LPKA.

The child victim, in this case socially, will certainly experience extraordinary and prolonged trauma and suffering for the rest of his life in facing his future life due to the actions committed by the two perpetrators, namely the child and the adult. This has been the main consideration of the Public Prosecutor so that the criminal charges imposed on the child perpetrators of crimes are not solely based on the legal certainty side, namely from the aspect of the application of the written law alone, but are also expected to be felt to provide a sense of justice and benefit or at least Whether or not the submission of criminal charges against the child perpetrator does not rule out the aspects of protection and a sense of justice given to the child victim and his family.

To get two goals that are fair and balanced for both parties, of course, requires the attitude of wisdom from law enforcement officials, especially in the context of prosecution by the Public Prosecutor. This wise attitude is certainly related to the deep understanding by the Public Prosecutor to always consider the values and laws that live and develop in society in every criminal charge he makes. Sri Endah Wahyuningsih argues that the source of the development of Indonesian criminal law can be from various sources, both taken from the law that lives and develops in society (local wisdom) or from foreign law by conducting comparative studies (international wisdom), ${ }^{21}$ This is the basis for aligning the social views that arise in response to criminal charges from the Public Prosecutor, especially in the case mentioned above, which of course is expected to be used as material for study, especially from philosophical and sociological aspects, especially views regarding justice and adequate protection for children who become victims. victims of a crime, although it is certainly a difficult matter and tends to be a very subjective view for the parties who judge considering that in the same incident, the Public Prosecutor must take an attitude that is considered the most fair and most balanced for both parties with different interests, namely the interests of the child and the interests of the victim's child.

Children as perpetrators of crimes by law are also given legal protection in the form of actions, meaning that in addition to imposing a criminal offense, whether it is a basic or additional criminal offense, it is also possible for children who are perpetrators of crimes to receive an action in the sense that the child who commits a crime is not sentenced but is sentenced, and this is one of the aims of legal reform in Indonesia regarding the settlement of juvenile criminal cases. The renewal of the criminal law on children has given birth to an alternative or method of resolving crimes committed by children which is considered the best solution in resolving criminal acts which involve children in it. ${ }^{22}$

\footnotetext{
${ }^{21}$ Sri Endah Wahyuningsih, 2018, Model Pengembangan Asas Hukum Pidana dalam KUHP Berbasis Nilai-nilai Ketuhanan Yang Maha Esa, Semarang, Fastindo, p.3

${ }^{22}$ Unbanunaek Mimi, Jimmy Pello, Karolus Kopong Medan, Diversi Dalam Perlindungan Hukum Anak Yang Bermasalah Hukum Dalam Sistem Peradilan Pidana Anak, Masalah-Masalah Hukum, Volume 43 No. 2, April 2014, p.308
} 
The national development policy in case of the development of national law must be based on the constitution as the supreme law of the land by mobilizing all the potential and capabilities of the available resources and estimating the conditions that affect it both on a national, regional and global scale as well as orderly steps in each of these efforts with national development goals. According to Paton, the essence of legal development is legal development and legal reform. Legal development is the maintenance of existing laws, not destroying but instead allowing them to grow, while legal reform is to form a new legal order. ${ }^{23}$

To impose an Action with the types as described in the discussion above, caution and wisdom are needed from law enforcement officials, especially the Public Prosecutor because the imposition of the said Action, although seen from the aspect of legal certainty, can be accounted for, but because of the imposition of the Action there is a written arrangement in in the law, but the side of legal certainty will definitely clash with the side of justice and the side of benefit for the victim's child, even though justice and benefit must both be achieved according to the objectives of the law itself as well as the ultimate goal from the point of view of legal philosophy.

In order to fulfill the sense of justice and benefit of children who are in conflict with the law, both as victims and as perpetrators, the rights of these children must be protected by the government. It should be noted that the obligation to provide protection for children is very necessary in accordance with the situation, condition, mental, physical, social conditions and abilities at a certain age. ${ }^{24}$

Regarding the studies discussed in the prosecution of criminal cases involving sexual intercourse involving child perpetrators with victims who are also still in the category of children, in the author's opinion, the imposition of actions as regulated in the law can be avoided except for imposing actions in the form of treatment in a mental hospital if the child is the perpetrator of the crime suffer from mental disorders, the rest concerns the form of imposition. Other actions should be avoided by law enforcement solely to ensure a sense of justice to provide benefits to the community, especially to child victims and their families.

From this point of view, it is possible for criminals with aspects of deprivation of liberty (criminal guidance in institutions and imprisonment) to be an alternative choice for law enforcement officials, especially for prosecutors in prosecuting criminal cases with child perpetrators and victims who are also still in the category of children, if the child's actions are It is seen that it has actually caused trauma and prolonged suffering for the victim's child, and this can be an alternative option that can be applied specifically to cases of obscenity or sexual intercourse with violence or threats of violence committed by the perpetrator's child with the victim who is also a child.

\footnotetext{
${ }^{23}$ Sri Endah Wahyuningsih, 2013, Perbandingan Hukum Pidana, Dari Perspektif Religius Law System, Second Print., Semarang, Unissula Press, p. 4.

${ }^{24}$ Slamet Riyadi, Pemidanaan Dan Perlindungan Anak Yang Berhadapan Dengan Hukumtindak Pidana Kesusilaan: Studi Kasus Putusan Nomor 30/PID.SUSANAK/2016/PN JKT. SEL, Jurnal Ilmiah WIDYA Yustisia, Volume 1 Nomor 2, 2019, p.130-138
} 
The demand from the Public Prosecutor which contains aspects of deprivation of liberty (in the form of imposing a criminal coaching in institutions and imprisonment) to the child must of course also be seen and studied with various existing provisions, especially regarding the rights of the child in article 3 of Act No. 11 of 2012 concerning the Juvenile Criminal Justice System which in letter $\mathrm{g}$ has outlined the right of children in conflict with the law not to be arrested, detained or imprisoned except as a last resort and in the shortest time. The clause that reads "last resort" is what opens the opportunity for the Public Prosecutor to not hesitate in filing charges in the form of imprisonment if viewed from a sociological and philosophical aspect, it is indeed felt to be able to provide a real sense of justice for the victim's child, family and community at the time generally.

Thus, the aspect of retaliation contained in the Combined Theory is currently considered still relevant to be considered for law enforcement officials to prosecute and impose criminal penalties in the form of imprisonment against child perpetrators, but this is wisely only applied to criminal cases with child perpetrators and victims as well as children with a very extraordinary impact for child victims, namely lifelong suffering (especially in cases of sexual abuse and child sexual intercourse).

In discussing the problem casuistically as mentioned above, the prosecutor's submission of criminal charges in the form of imprisonment for the child of the perpetrator, when viewed from a sociological aspect, it seems that there is an element of revenge against the perpetrator, but it is the element of revenge that is actually expected by the child of the victim and their families, because that is what is seen as capable of giving them a sense of justice. However, on a case-by-case basis, the imposition of imprisonment on the perpetrator's child must also continue to pay attention to the aspect of protection for the child perpetrator in accordance with the provisions of positive law in force in Indonesia, including by imposing a prison sentence for the shortest period of time as mandated in the provisions of Article 3 letter $g$ of the Law.

\section{Closing}

The Prosecutor's claim against the Child of Bagus Andriyanto Bin Ahmad Sujio has been appropriately applied in the context of legal protection to the Child Victim because the claim is formal and material and is also seen from the aspect of the legal objective in accordance with the provisions of the existing legislation which is formally regulated in Article 71 of Act No. 11 of 2012 concerning the Juvenile Criminal Justice System, besides that from a sociological and philosophical point of view that is based on a sense of justice and benefit for the benefit of the victim's child and his family, the Prosecutor's claim in question contains aspects of deprivation of liberty against the child perpetrator of the crime. It has been felt that it is comparable to the trauma and lifelong suffering experienced by the victim's child in facing his future. In the context of legal protection by the State to victims of crime, it is recommended that the Public Prosecutor who handle cases of sexual crimes committed by children against children not hesitate to choose to file criminal charges against the perpetrator's child with a criminal charge in which 
there is an aspect of deprivation of liberty (can be in the form of criminal coaching) in an institution or imprisonment), but this must be done wisely and wisely with deep consideration, namely if the actions of the perpetrator's Child have actually caused lifelong trauma and suffering for the Child Victim and his family. The submission of criminal charges with the aspect of deprivation of liberty must also be carried out by the Public Prosecutor without compromising the aspect of protection for the future of the child who perpetrates the crime in accordance with the provisions. Article 3 letter g of Act No. 11 of 2012 concerning the Juvenile Criminal Justice System.

\section{References}

\section{Books}

[1] Bambang Purnomo, 1982, Asas-Asas Hukum Pidana, Jakarta, Ghalia Indonesia;

[2] Barda Nawawi Arief, 1998, Beberapa Aspek Kebijakan dan Pengembangan Hukum Pidana, Bandung, PT. Citra Aditya Bakti;

[3] H.R. Abdussalam dan Adri Deasasfuryanto, 2014, Hukum Perlindungan Anak, Jakarta, PTIK;

[4] Maidun Gultom, 2013, Perlindungan Hukum Terhadap Anak Dan Perempuan, Refika Aditama, Bandung;

[5] Nandang Sambas, 2013, Peradilan Pidana Anak di Indonesia dan Instrumen International Perlindungan Anak serta Penerapannya, Yogyakarta, Graha Ilmu;

[6] Sri Endah Wahyuningsih, 2013, Perbandingan Hukum Pidana, Dari Perspektif Religius Law System, Second Print., Semarang, Unissula Press;

[7] Sri Endah Wahyuningsih, 2018, Model Pengembangan Asas Hukum Pidana dalam KUHP Berbasis Nilai-nilai Ketuhanan Yang Maha Esa, Semarang, Fastindo;

[8] Sri Sumarwani, 2012, Pidana dan Hak-Hak Manusia, Ed. I, Semarang, UNDIP Pres;

\section{Journals}

[1] Analiansyah dan Syarifah Rahmatillah, Perlindungan Terhadap Anak Yang Berhadapan Dengan Hukum (Studi Terhadap Undang-undang Peradilan Anak Indonesia dan Peradilan Adat Aceh), Gender Equality: Internasional Journal of Child and Gender Studies, Vol. 1, No. 1, March 2015;

[2] Ari Yudistira and Widayati, The Investigation Process of Prospective Children in Criminal Action, Jurnal Daulat Hukum, Volume 4 Issue 1, March 2021;

[3] Bagus Gede Brahma Putra, Gde Made Swardhana, Sagung Putri M.E. Purwani, Anak Berhadapan Dengan Hukum Ditinjau Dari Aspek Kriminologi (Study Kasus Di Lembaga Pembinaan Khusus Anak Kelas Ii Karangasem), Kertha Wicara, Vol. 07, No. 01, Januari 2018;

[4] I Dewa Putu Gede Anom Danujaya, Formulasi Model Sistem Pemidanaan Anak Di Indonesia, Jurnal Daulat Hukum, Volume 1 Issue 1, March 2018;

[5] Mahendra Ridwanul Ghoni, P.Pujiyono, Perlindungan Hukum Terhadap Anak yang Berhadapan dengan Hukum Melalui Implementasi Diversi di Indonesia, Jurnal Pembangunan Hukum Indonesia, Volume 2, Nomor 3, 2020; 
[6] Putu Yudha Cahyasena, I Ketut Rai Setiabudhi, I Made Tjatrayasa, Tinjauan Kriminologis Terhadap Anak Yang Berkonflik Dengan Hukum (Study Kasus Di Bapas Kelas Ii Mataram), Kertha Wicara, Vol. 05, No. 03, April 2016;

[7] Rachmadhani Mahrufah Riesa Putri, Subekti, Tindak Pidana Penyalahgunaan Narkotika Pada Anak Dalam Hukum Positif Di Indonesia, Recidive, Volume 8 No. 3, Sept.-Dec 2019;

[8] Rendy Surya Aditama, Umar Ma'ruf, Munsharif Abdul Chalim, Kebijakan Hukum Pidana Terhadap Anak Sebagai Pelaku Kejahatan Psikotropika Di Kepolisian Resor Magelang, Jurnal Daulat Hukum, Vol. 1. No. 1 March 2018;

[9] Rini Fitriani, Peranan Penyelenggara Perlindungan Anak Dalam Melindungi dan Memenuhi Hak-Hak Anak, Jurnal Hukum Samudra Keadilan, Vol 11, No 2, July-December 2016;

[10] Slamet Riyadi, Pemidanaan Dan Perlindungan Anak Yang Berhadapan Dengan Hukumtindak Pidana Kesusilaan: Studi Kasus Putusan Nomor 30/PID.SUSANAK/2016/PN JKT. SEL, Jurnal Ilmiah WIDYA Yustisia, Volume 1 Nomor 2 May 2019;

[11] Sri Endah Wahyuningsih, Rismanto, Kebijakan Penegakan Hukum Pidana Terhadap Penanggulangan Money Laundering Dalam Rangka Pembaharuan Hukum Pidana Di Indonesia, Jurnal Pembaharuan Hukum, Volume II No. 1 January-April 2015;

[12] Unbanunaek Mimi, Jimmy Pello, Karolus Kopong Medan, Diversi Dalam Perlindungan Hukum Anak Yang Bermasalah Hukum Dalam Sistem Peradilan Pidana Anak, Masalah-Masalah Hukum, Jilid 43 No. 2, April 2014;

\section{Regulation}

a. Constitution of the Republic of Indonesia 1945;

b. Law of the Republic of Indonesia Number 8 of 1981 concerning the Criminal Procedure Code (KUHAP);

c. Criminal Code (KUHP);

d. Law of the Republic of Indonesia Number 16 of 2004 concerning the Indonesian Prosecutor's Office;

e. Act No. 23 of 2002 concerning Child Protection;

f. Act No. 35 of 2014 concerning Amendments to Act No. 23 of 2002 concerning Child Protection;

g. Government Regulation in Lieu of Act No. 1 of 2016 concerning the Second Amendment to Act No. 23 of 2002 concerning Child Protection;

h. Act No. 17 of 2016 concerning Stipulation of Government Regulations in Lieu of Act No. 1 of 2016 concerning Child Protection to become Laws;

i. Act No. 11 of 2012 concerning the Juvenile Criminal Justice System. 